\title{
ENERGETICS OF THE HIGH FREQUENCY DISTURBANCES OVER SOUTH AMERICA
}

\author{
M. A. Gan \& V. B. Rao
}

\begin{abstract}
The energetics of the high frequency disturbances over South America are studied using composite maps of cyclone systems. The composite maps are constructed with filtered geopotential height data at $1000 \mathrm{hPa}$ for the days when negative anomalies at the base grid point $70^{\circ} \mathrm{W}, 45^{\circ} \mathrm{S}$ exceeded two standard deviations below the mean. The cyclone system composite has 61 cases. The spatial distribution of the available potential energy of the high frequency disturbances is similar to what is seen for the Northern Hemisphere extratropical cyclones. The energy cycle of the high-pass filtered anomalies showed that these disturbances grow by baroclinic conversion. During the growing phase, energy fluxes coming into the region and nonconservative sources are also important, although barotropic instability seems to play some role over the Pacific Ocean. At the mature stage the disturbances showed barotropic decay and radiate energy out of the region.
\end{abstract}

Key words: High frequency disturbance; Energy cycle; Baroclinic instability.

ENERGETICA DOS DISTÚRBIOS DE ALTA FREQÜÊENCIA SOBRE A AMÉRICA DO SUL- A energética dos distúrbios de alta freqüência é estudada por compostos dos sistemas ciclônicos. Os mapas compostos são construídos com dados filtrados da altura geopotencial em 1000 hPa para os dias em que a anomalia negativa no ponto base $70^{\circ} \mathrm{W}, 45^{\circ} \mathrm{S}$ estava abaixo de dois desvios padrões. Foram obtidos 61 compostos de sistemas ciclônicos. A distribuição espacial da energia potencial disponível dos distúrbios de alta freqüência é similar àquela obtida para os ciclones extratropicais do Hemisfério Norte. O ciclo de energia das anomalias filtradas com passa alta mostra que esses distúrbios crescem por conversões baroclínicas. Durante a fase de crescimento, fluxos de energia chegando na região e as fontes não conservativas são também importantes, embora a instabilidade barotrópica parece ter um papel importante sobre o oceano Pacífico durante essa fase. No estágio maduro, o distúrbio começa a decair barotropicamente e a energia radiativa é exportada para fora da região.

Palavras-Chave: Distúrbio de alta freqüência; Ciclo de energia; Instabilidade baroclínica

Instituto Nacional de Pesquisas Espaciais - INPE, C.P. 515,

12201-970, São José dos Campos, SP, Brazil

alonso@met.inpe.br 


\section{INTRODUCTION}

The atmosphere is a complex thermodynamic system in which conversions of energy on both temporal and spatial scale are involved. Spatial scale conversions have been largely studied after Lorenz (1955) who introduced the concept of available potential energy (APE) and partitioned kinetic energy (KE) in two components: zonal mean and eddy. Unfortunately global analysis of eddy energy components smoothes out the results of the contribution of individual systems which often have substantial rates of energy transformation but are relatively limited in their horizontal extent. Several studies have examined the eddy energy with analysis of individual circulation systems.

Hayashi (1980) proposed a scheme that decomposes meteorological time series into Fourier components so that energy conversions can be viewed through spectra of different frequency ranges. With this scheme it is possible to study the interactions among disturbances of different time scales. Sheng \& Hayashi (1990) applied this analysis of spectral energetics in the frequency domain for a version of the First Garp (Global Atmospheric Research Program) Global Experiment (FGGE) IIIb dataset, processed at Geophysical Fluid Dynamics Laboratory (GFDL) and European Center for Medium Range Weather Forecasts (ECMWF). In their study, they noted that the APE is generated by diabatic processes almost entirely in the components of the time averaged flow and the variations of the annual cycle. This energy is exchanged with shorter time scales by the eddy heat transport processes. Potential energy is also converted into kinetic energy at all time scales but this conversion is mostly concentrated in two frequency regions: the time mean with 35 percent and high frequencies (period shorter than 10 days) with 22 percent. Because of the nonlinear exchange, kinetic energy is lost at high frequencies and gained at low frequencies, except for the annual cycle. They also observed that high frequency disturbances have an energy cycle very similar to that of the classical picture given by Oort (1964). In this picture, the mean differential heating generates the time-mean APE and the baroclinic transient disturbances transform the time mean APE into the synoptic scale APE. Then, the transient APE is converted into transient $\mathrm{KE}$ by the vertical motions of the high frequency disturbances and the KE of the time mean flow is maintained by barotropic conversion of transient $\mathrm{KE}$.

In the low baroclinicity regions convergence of horizontal fluxes rather than energy conversion might become important. The development of baroclinic waves over low baroclinicity region associated with ageostrophic geopotential fluxes was proposed by Orlanski \& Katzfey (1991) for South hemisphere and Chang \& Orlanski (1993) for North Hemisphere. They found that when a wave has a sufficiently large amplitude, the horizontal poleward heat flux can attain a maximum amplitude. At this stage, the ageostrophic fluxes also become very large and, on the downstream side of the eddy rinetic energy center, these fluxes are strongly divergent. Farther downstream, the fluxes become convergent, triggering the development of a new energy center.

In the present paper we discuss energetics of the high frequency disturbances when they cross the Andes Cordillera utilizing formulation similar to that given by Plumb (1983). The South American region is cyclogenetic (Gan \& Rao, 1991) and sometimes the transient disturbances intensify after crossing the Andes. This indicates local exchanges of energy. Thus the present study has important implications for the forecasting of cyclogenesis. In section 2, the data source and the methodology are briefly discussed. The results of the energy cycle of the high frequency disturbances are presented in section 3 . The results are summarized in section 4.

\section{DATA AND METHODOLOGY}

In this study we used zonal wind, meridional wind, temperature and geopotential height data for 10 levels between $1000 \mathrm{hPa}$ and $100 \mathrm{hPa}$, for the period 1 January 1977 through 31 December 1979. These were the twice daily analyses provided by the National Meteorological Center (NMC) of United States of America and are on a $2.5^{\circ} \times 2.5^{\circ}$ longitude $\mathrm{x}$ latitude grid. However because of the short memory of the computer on hand only $5^{\circ} \times 5^{\circ}$ grid point data were used. Data were missing for the period of 16 June 1977 through 31 July 1977. Other missing one day data were linearly interpolated.

Although earlier study by the authors (Gan \& Rao, 1991) showed that over the east coast of Patagonia the frequency of cyclogenesis is more in summer than winter, in the present analysis no attempt is made to separate the data by season. Randel \& Stanford (1985a, b, c) have shown that transient baroclinic disturbances occur in the Southern Hemisphere during summer also. In a future study the summer and winter differences should be studied. We made use of high-pass filtered data with periods shorter than 5 days and low-pass filtered data with periods higher than 5 days. Both filters used are of a Gaussian type with 9 points in the time series, and it is essentially the same as that used earlier by Lau \& Lau (1984), Hsu (1987) and Gan \& Rao (1994).

The conventional formulation has to be changed to suit the present case. The conventional formulation makes use of zonal means and zonal deviations (eddy components). In the present study, however local interactions between a quasi-stationary component, represented by low pass filtered variables and a transient component represented by highpass filtered variables are examined. The formulation used here is similar to that given by Plumb (1983), but the convergence of eddy geopotential fluxes is included in the residual term:

$$
\frac{\partial \mathrm{APH}}{\partial t}=\mathrm{CA}-\mathrm{PK}+\mathrm{R}_{\mathrm{AP}}
$$




$$
\begin{aligned}
& \frac{\partial \mathrm{KEH}}{\partial t}=\mathrm{PK}-\mathrm{CK}+\mathrm{R}_{\mathrm{KE}} \\
& A P H=\int \frac{T_{h}^{2}}{2 \sigma} d p \\
& K E H=\frac{1}{g} \int \frac{u_{h}^{2}+v_{h}^{2}}{2} d p \\
& C A=-\int \frac{1}{\sigma}\left(u_{h} T_{h} \frac{\partial T_{1}}{\partial X}+v_{h} T_{h} \frac{\partial T_{1}}{\partial Y}\right) d p \\
& C K=-\frac{1}{g} \int\left(u_{h} u_{h} \frac{\partial u_{1}}{\partial X}+v_{h} u_{h} \frac{\partial u_{1}}{\partial y}+\right. \\
& \left.v_{h} u_{h} \frac{\partial v_{1}}{\partial x}+v_{h} v_{h} \frac{\partial v_{1}}{\partial Y}\right) d p \\
& P K=-\int \frac{R}{g p} \omega_{h} T_{h} d p,
\end{aligned}
$$

where APH and $\mathrm{KEH}$ are, respectively, the available potential energy and kinetic energy of the high-pass disturbances. CA and $\mathrm{CK}$ are measures of the conversion of available potential energy and kinetic energy from the quasistationary flow into the high-pass disturbances and PK represents the conversion of available potential energy of high-pass disturbances into kinetic energy. $\mathrm{R}_{\mathrm{AP}}$ and $\mathrm{R}_{\mathrm{KE}}$ are residual terms and represent also the advection by mean flow, nonconservative source/sink and fluxes of the available potential energy and kinetic energy of the high-pass disturbances, respectively. These terms are calculated as budget residuals. The subscripts ${ }_{h}$ and denote high-pass and low pass filtered data, respectively, $\mathrm{s}$ is the area averaged static stability parameter and is considered to depend only on time and pressure, $\mathrm{g}$ is the gravitation acceleration, $\mathrm{w}$ is the vertical velocity, calculated kinematically from the continuity equation. An adjustment of mass is made by the method suggested by O'Brien (1970). The vertical integration is perfomed from 1000 to $100 \mathrm{hPa}$. Time derivatives are approximated by a 12-hour forward and backward time difference, then averages are taken to obtain the terms on the left hand of Eqs (1) and (2). For example for three points $-2,-1,0 \partial x / \partial t$ is approximated as $\left[\left(\mathrm{X}_{-1}-\right.\right.$ $\left.\left.\mathrm{X}_{-2}\right) / \mathrm{Dt}+\left(\mathrm{X}_{0}-\mathrm{X}_{-1}\right) / \mathrm{Dt}\right] / 2$ which is valid at " -1 " day.

The energy cycle is studied with composite maps of the systems. The case shown here is the same as that utilised by Gan \& Rao (1994) (see Figs. 14 and 17 for cyclonic system composite of Gan \& Rao, 1994). The criterion used by Gan \& Rao (1994) to construct the composite maps is as follow: first the point which exceeded two standard deviation of filtered geopotential height of $1000 \mathrm{hPa}$ at the base grid point $\left(70^{\circ} \mathrm{W}, 45^{\circ} \mathrm{S}\right)$ are selected. These are marked as $\mathrm{X}$ in Fig. 1. Then means of the geopotential height at each grid point of all the selected cases are taken, thus making a composite map for each time ( -2 days, -1 day, $0,+1$ day, +2 days). The cyclone system composite has 61 cases of negative deviations.

\section{RESULTS}

The maps of cyclone system composite for $1000 \mathrm{hPa}$ obtained by Gan \& Rao (1994) (Fig.2) show a tendency for the disturbances to intensify over the eastern Pacific Ocean and over South America. Over the continent there is a division of the center of the disturbance - one center moves to north of Argentina and the other center moves over the Atlantic Ocean. These two centers represent the cyclogenesis over north Argentina and Uruguay and the transient cyclone systems with zonal propagation. Although the cyclone systems have different tracks and velocities, most of them have the evolution similar to that given in Fig.2. The cyclone system composite has both genesis and intensification. The smaller value of filtered geopotential height during the -1 and +1 days is representative of evolution of transient cyclones.

The energy cycle for the cyclone system composite shows that the available potential energy of the high

\begin{tabular}{|c|r|r|r|}
\hline & -1 & 0 & +1 \\
\hline$\frac{\partial \mathrm{A} \mathrm{PH}}{\partial \mathrm{t}}$ & 15.3 & 5.1 & -11.2 \\
\hline $\mathrm{C} \mathrm{A}$ & 2.3 & 6.4 & 3.6 \\
\hline P K & 2.9 & 3.3 & -1.0 \\
\hline R A P & 15.9 & 2.0 & -15.8 \\
\hline
\end{tabular}

Table 1 - Available potential energy budget of high-pass filtered disturbances for cyclonic system composite, for one day earlier (1 ) at the same time (0), one day later (+1). Units $\mathrm{Wm}^{-2}$.

Tabela 1 - Saldo da energia potencial disponível dos distúrbios filtrados com passa alta para o composto de sistemas ciclônicos para um dia (-1), a mesmo instante (0), um dia depois (+1). Unidades $\mathrm{Wm}^{-2}$.

\begin{tabular}{|c|r|r|r|}
\hline & -1 & 0 & +1 \\
\hline$\frac{\partial \mathrm{K} \mathrm{E} \mathrm{H}}{\partial t}$ & 26.1 & 4.7 & -21.8 \\
\hline $\mathrm{CK}$ & -0.3 & -0.7 & -0.1 \\
\hline $\mathrm{P} \mathrm{K}$ & 2.9 & 3.3 & -1.0 \\
\hline $\mathrm{R}_{\mathrm{KE}}$ & 22.9 & 0.7 & -20.9 \\
\hline
\end{tabular}

Table 2 - Kinetic energy budget of high-pass filtered disturbances for cyclonic system composite, for one day earlier (-1) at the same time $(0)$, one day later $(+1)$. Units $\mathrm{Wm}^{-2}$.

Tabela 2 - Saldo da energia cinética dos distúrbios filtrados com passa alta para o composto de sistemas ciclônicos ciclônicos para um dia (-1), a mesmo instante (0), um dia depois $(+1)$. Unidades $W m^{-2}$. 


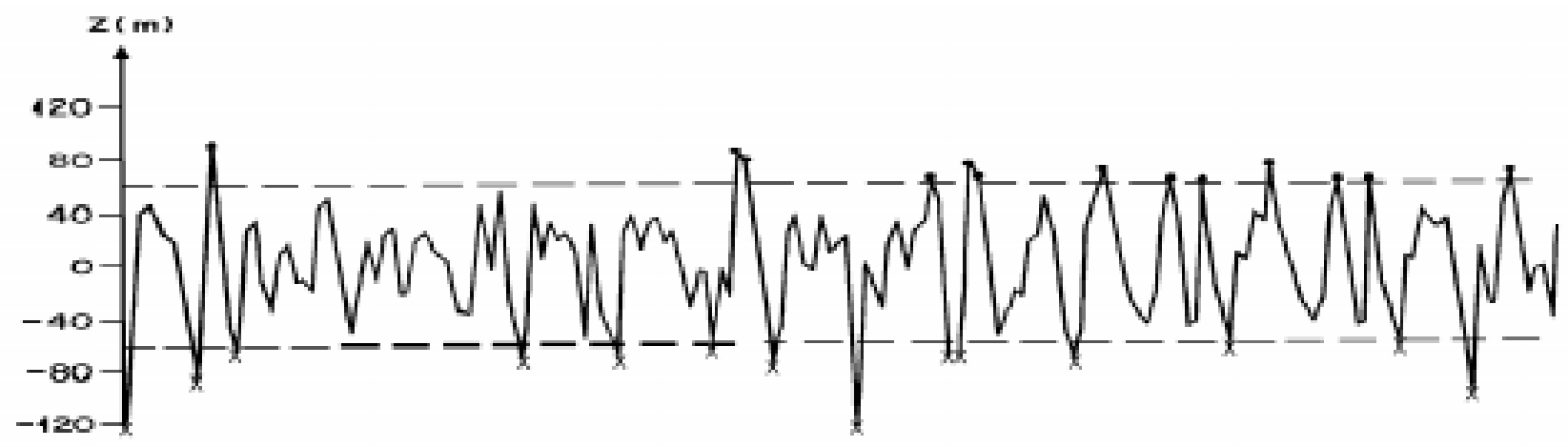

$45^{\circ} \mathrm{S}$ ). The point $\mathrm{X}$ are those which exceed two standard deviations (given by the horizontal dashed line).

Figura 1 - Serie temporal da altura geopotencial em 1000-hPa dos dados filtrados com passa alta de Maio 1977 Agosto de 1977 no ponto de grade $\left(70^{\circ} \mathrm{W}, 45^{\circ} \mathrm{S}\right)$. O ponto $\mathrm{X}$ são aqueles na qual o geopotencial excede dois desvios (dados pela linha horizontal tracejada).

frequency disturbances (APH) (Fig. 3) increases as the cyclones intensify. The maximum APH is located downstream the cyclone by about $5^{\circ}$ at $1000 \mathrm{hPa}$. This is similar to what happens in the case of extratropical cyclones of Northern Hemisphere (Lin \& Smith, 1979). On day -1 a center of APH can be seen on the east side of South America (near $35^{\circ} \mathrm{S}, 60^{\circ} \mathrm{W}$ ). On day +1 the centers of APH associated with the cyclonic system become elongated covering the region of the two maxima.

The spatial distribution of kinetic energy of high frequency disturbances (KEH) (Fig. 4) has the evolution similar to that of APH during the days -1 and 0 . On day +1 (Fig. 4c) we can see an elongation of maximum over the Atlantic ocean and Argentina.

The maps of term CA (the conversion of APE from quasi-stationary flow into the high frequency disturbance) (Fig. 5) show a wave pattern with positive values located $5^{\circ}$ to the east of the cyclone at $1000 \mathrm{hPa}$. This positiveness is an indication that quasi-stationary APE is getting converted into APH. Our calculations show that the second term on the right hand side of Eq. (5) dominates in the CA term, and this conversion is associated with the poleward heat transport due to the air from the Subtropical South Atlantic high (James \& Anderson, 1984). During the decay, the term CA continues to be positive, indicating that other processes are necessary to dissipate the cyclonic system.

The term that converts APH into KEH (term PK) (Fig. 6) shows positive values at the cyclonic position on day -1 , this conversion is to northeast of the cyclonic system on day 0 . On day +1 , the map of the term PK shows a center of positive values at the position of the cyclone system over the South Atlantic ocean. This indicates that these disturbances are growing baroclinically extracting potential energy from the quasi-stationary flow and converting into $\mathrm{KEH}$. This is consistent with the upper-level wave structure. Gan \& Rao (1994) compared the high frequency anomalies at $300 \mathrm{hPa}$ with the $1000 \mathrm{hPa}$ and noted that the centers at $300 \mathrm{hPa}$ were located to the west of the centers at $1000 \mathrm{hPa}$ by about one-quater wavelength.

The maps of the barotropic conversion - term CK
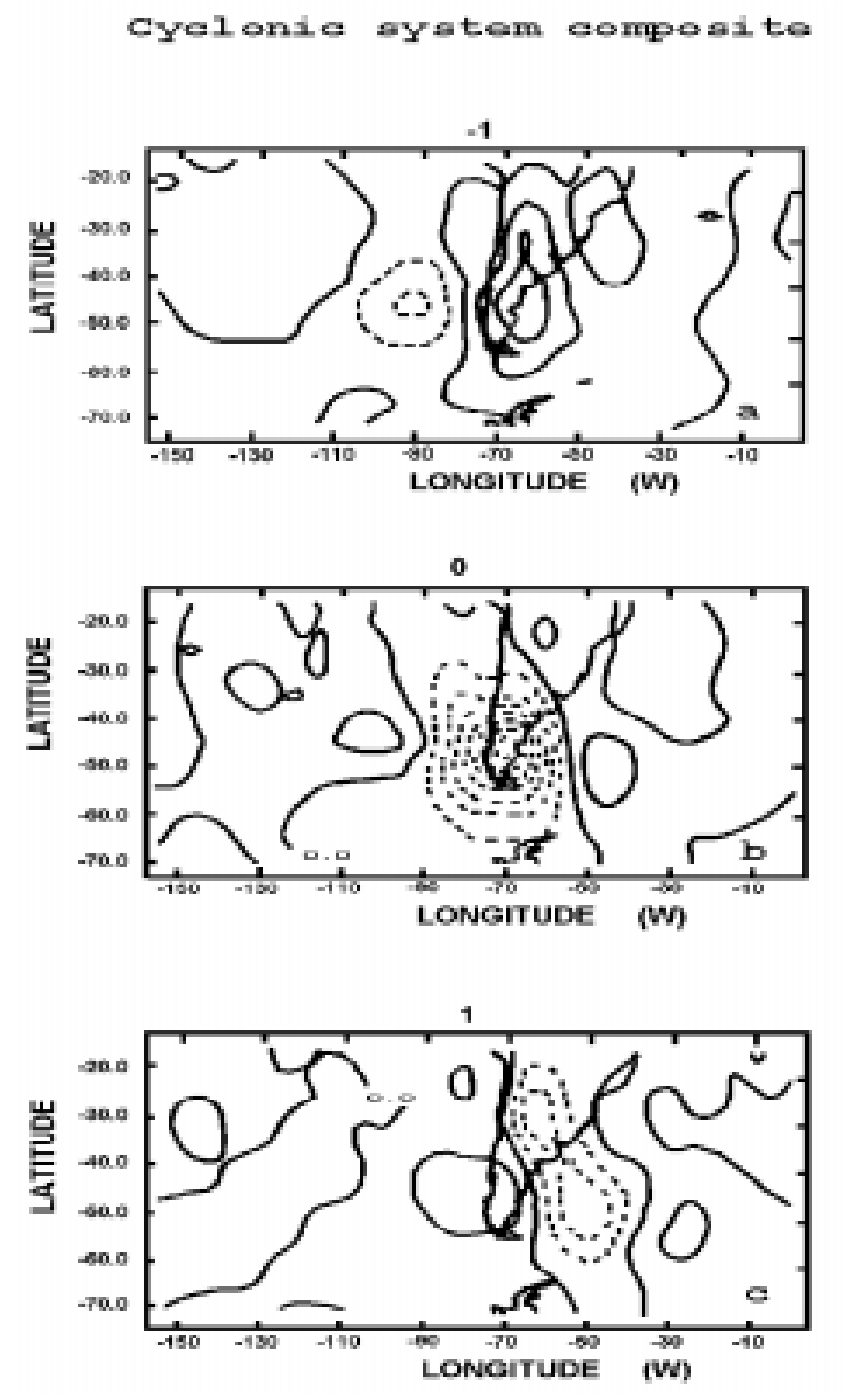

Figure 2 - Cyclonic system composite of high-pass filtered 1000-hPa geopotential data. The contour interval is $10 \mathrm{~m}$ : a) 1 day earlier, b) at the same time and c) 1 day later.

Figura 2 - Composto para o sistema ciclônico dos dados de geopotencial em $1000 \mathrm{hPa}$ filtrados com passa alta. O intervalo dos contornos é $10 \mathrm{~m}$ : a) 1 dia antes, b) no mesmo instante e c) 1 dia depois. 

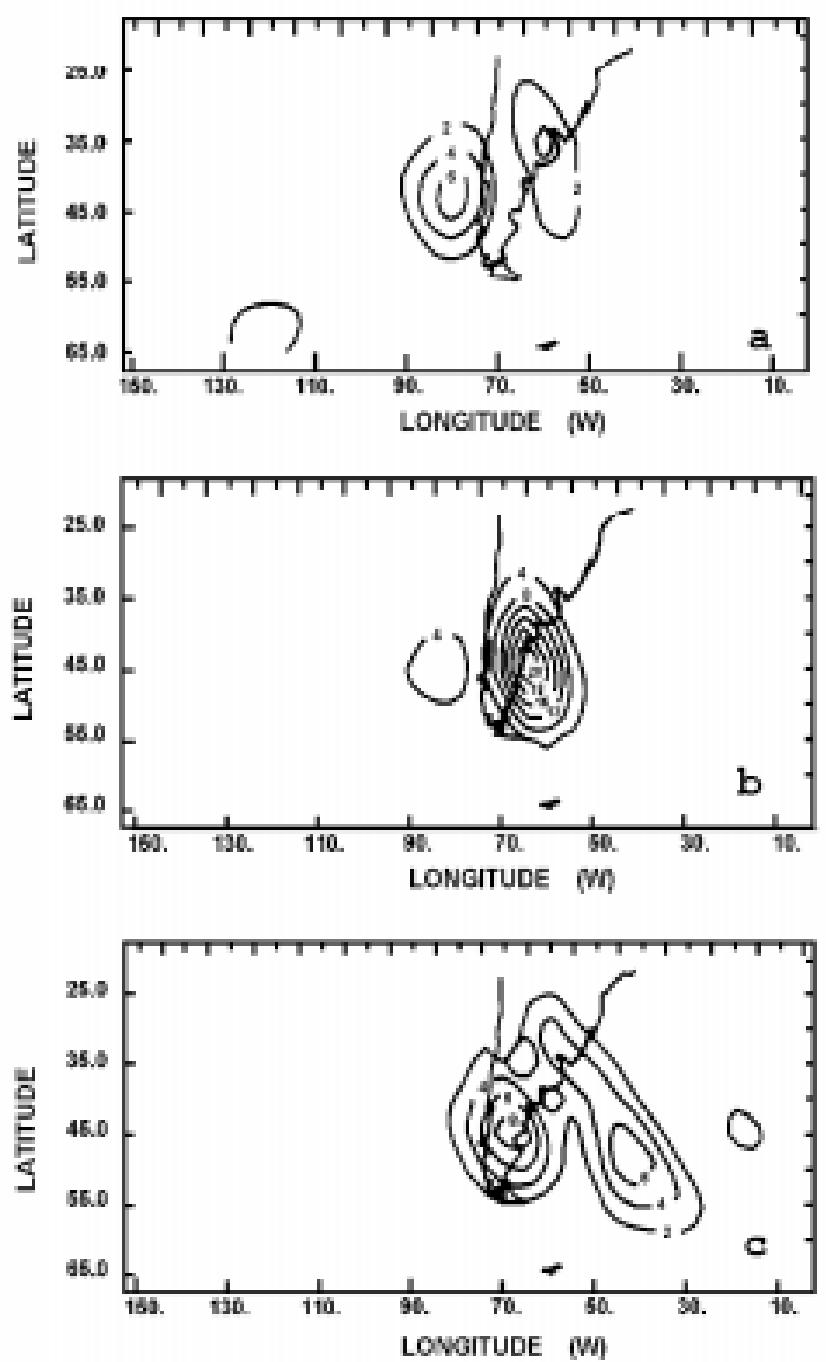

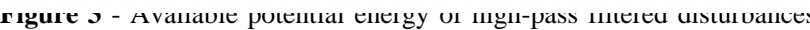
for cyclonic system composite. Base grid point $45^{\circ} \mathrm{S}, 70^{\circ} \mathrm{W}$. Units $10^{5}$ $\mathrm{Jm}^{-2}:$ a) one day earlier, b) at the same time, c) one day later.

Figura 3 - Energia potencial disponível dos distúrbios filtrados com passa alta para o composto de sistemas ciclônicos. Ponto base da grade $45^{\circ} \mathrm{S}$, $70^{\circ} \mathrm{W}$. Unidades $10^{5} \mathrm{Jm}^{-2}:$ a) ) 1 dia antes, $b$ ) no mesmo instante, c) 1 dia depois.

(conversion of kinetic energy from the quasi-stationary flow into the high frequency disturbances) show a maximum of CK over eastern South Pacific near the disturbance on day 1 (Fig. 7a) but its value is small compared with the baroclinic conversion. This result indicates that over eastern South Pacific the high frequency disturbances grow by barotropic conversion also. This agrees with Lau \& Lau (1984) for Pacific ocean near $150^{\circ} \mathrm{E}$ but disagrees with Wallace \& Lau (1985) who observed that the high frequency transients lose kinetic energy to mean flow at the jet stream level, while low frequency transients extract kinetic energy from the mean flow. When the disturbance crosses the Andes (days 0) (Fig. 7b) it produces negative values of the term CK over the South America region, and the process of the decay of
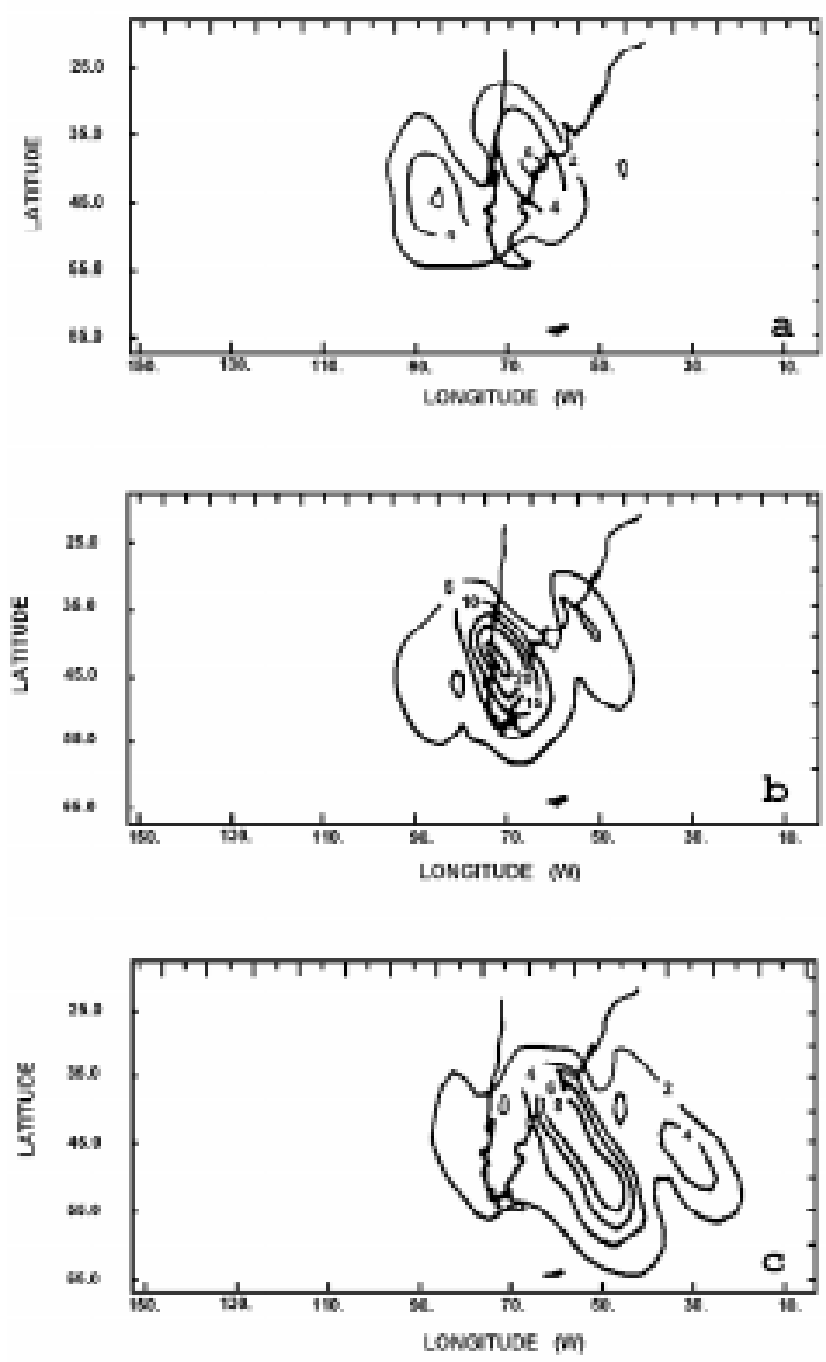

system composite. Base grid point $45^{\circ} \mathrm{S}, 70^{\circ} \mathrm{W}$. Units $10^{5} \mathrm{Jm}^{-2}$ : a) one day earlier, b) at the same time, c) one day later.

Figura 4 - Energia cinética dos distúrbios filtrados com passa alta para o composto de sistemas ciclonicos. Ponto base da grade $45^{\circ} \mathrm{S}, 70^{\circ} \mathrm{W}$. Unidades $10^{5} \mathrm{Jm}^{-2}$ : a) 1 dia antes, b) no mesmo instante, c) 1 dia depois.

the disturbance begins.

The balance of available potential energy and kinetic energy of high-pass filtered cyclonic system composite is calculated for the region encompassed between $30^{\circ} \mathrm{S}-55^{\circ} \mathrm{S}$ and $25^{\circ} \mathrm{W}-100^{\circ} \mathrm{W}$. The values of the terms of the equations 1 and 2 are given in tables 1 and 2, respectively. In both the cases the terms $R_{A P}$ and $R_{K E}$ are of the same order of magnitude as $\partial \mathrm{APH} / \partial \mathrm{t}$ and $\partial \mathrm{KE} / \partial \mathrm{t}$, respectively, on days -1 and +1 . But on the day 0 the terms $R_{A P}$ and $R_{K E}$ are much smaller. These results show that during the growing phase the nonconservative source (or sink) and the convergence of energy fluxes can be also play an important role in the development of the cyclonic system in addition to the baroclinic conversion terms. At the mature phase, however, 
Cenversion term between available potential energy of quasi-stationary flow and ADH
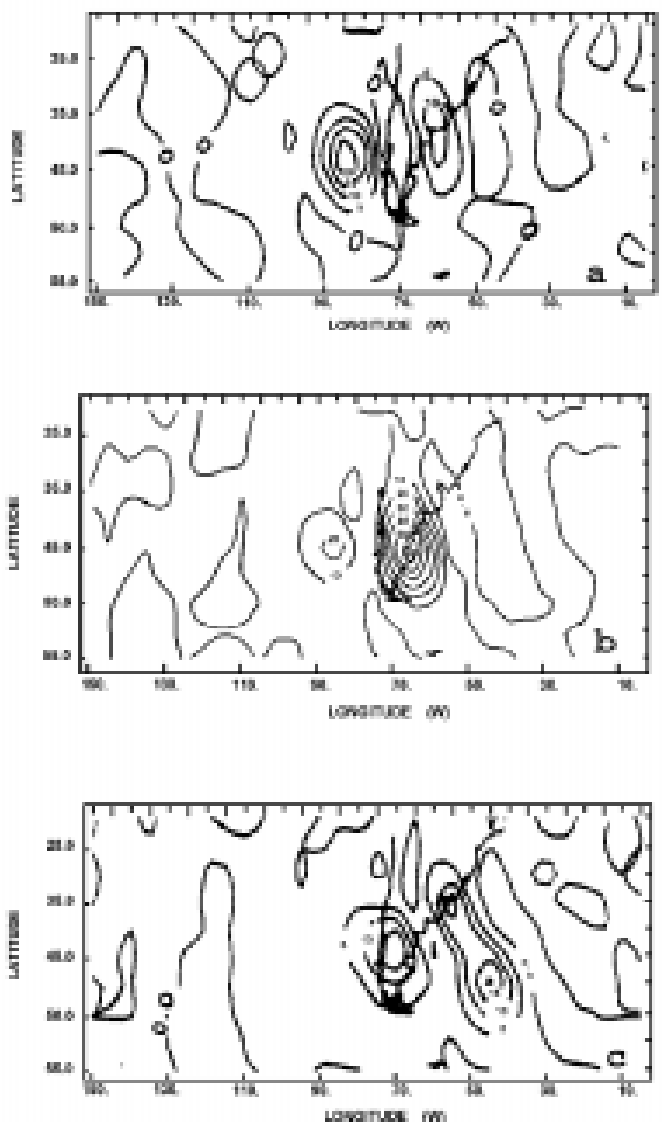

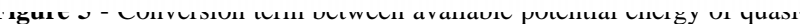
stationary flow and available potential energy of the high-pass filtered disturbances for cyclonic system composite. Units $\mathrm{Wm}^{-2}$. a) one day earlier, b) at the same time, c) one day later.

Figura 5 - Termo de conversão entre aenergia potencial disponível do escoamento quase estacionário e a energia potencial disponível dos distúrbios filtrados com passa alta para o composto de sistemas ciclonicos. Unidade $\mathrm{Wm}^{2}$. a) 1 dia antes, b) no mesmo instante, c) 1 dia depois.

the baroclinic terms (CA and PK) are more important and in the decay phase there are energy fluxes going out of the region to during the development (decay) stage of the cyclone. They also found that when the wave attained a sufficiently large amplitude, the horizontal heat flux poleward reached its maximum value. The ageostrophic fluxes become very large at this stage and, on the downstream side of the eddy kinetic energy center, they become strongly divergent. Father downstream, these fluxes became convergent, triggering the development of a new energy center. Chang (1993) found that over the less baroclinic eastern North Pacific region, waves grow mainly due to the convergence of energy fluxes radiated by the waves upstream, and they in turn decay by radiating fluxes toward the downstream direction, leading to the growth of a new wave farther downstream.

The presence of Andes, as a natural block, is a crucial factor to increase the low-level moist and hot air flux poleward (James \& Anderson, 1984). When the moist and hot tropical air entrain into mid-latitude depression, there is
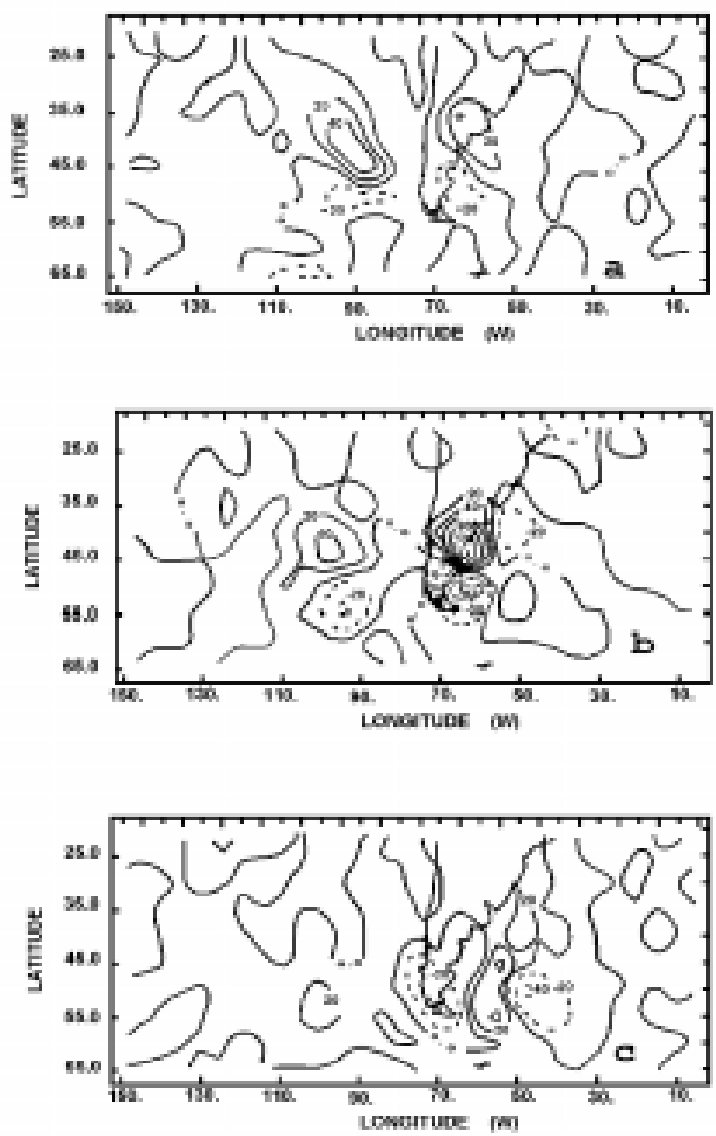

Figure o - Conversion term trom avaılable potentıal energy into kinetic energy of the high filtered disturbances for cyclonic system composite. Units $\mathrm{Wm}^{-2}$. a) one day earlier, b) at the same time, c) one day later.

Figura 6 - Termo de conversão entre a energia potencial dos distúrbios filtrados com passa alta e a energia cinética para o composto de sistemas ciclônicos. Unidades $W^{-2}$. a) 1 dia antes, b) no mesmo instante, c) 1 dia depois.

release of latent heat as a result of condensation. The release of latent heat increases the growth rate of the baroclinic disturbances (Bonatti \& Rao, 1987). This probably explains the high value of $\mathrm{R}_{A P}$ in the initial phase.

\section{CONCLUDING REMARKS}

The results presented here regarding the energetics of systems associated with high frequency anomalies over South America showed that these disturbances grow due to baroclinic conversion. However, the energy fluxes coming into the region and nonconservatives sources can be also important. After reaching maturity these disturbances start decaying barotropically and radiate energy out of the region. Over the Pacific Ocean however they can grow by barotropic energy conversion also. The energy cycle of these disturbances seem to be similar to that observed by Chang (1993) and Orlanski \& Katzfey (1991) for baroclinic disturbances that grow over the eastern North Pacific Ocean and eastern South Pacific, respectively. In our case, the 
Conversion term between kinetic energy of quasi-stationary flow and $\mathrm{KrH}$
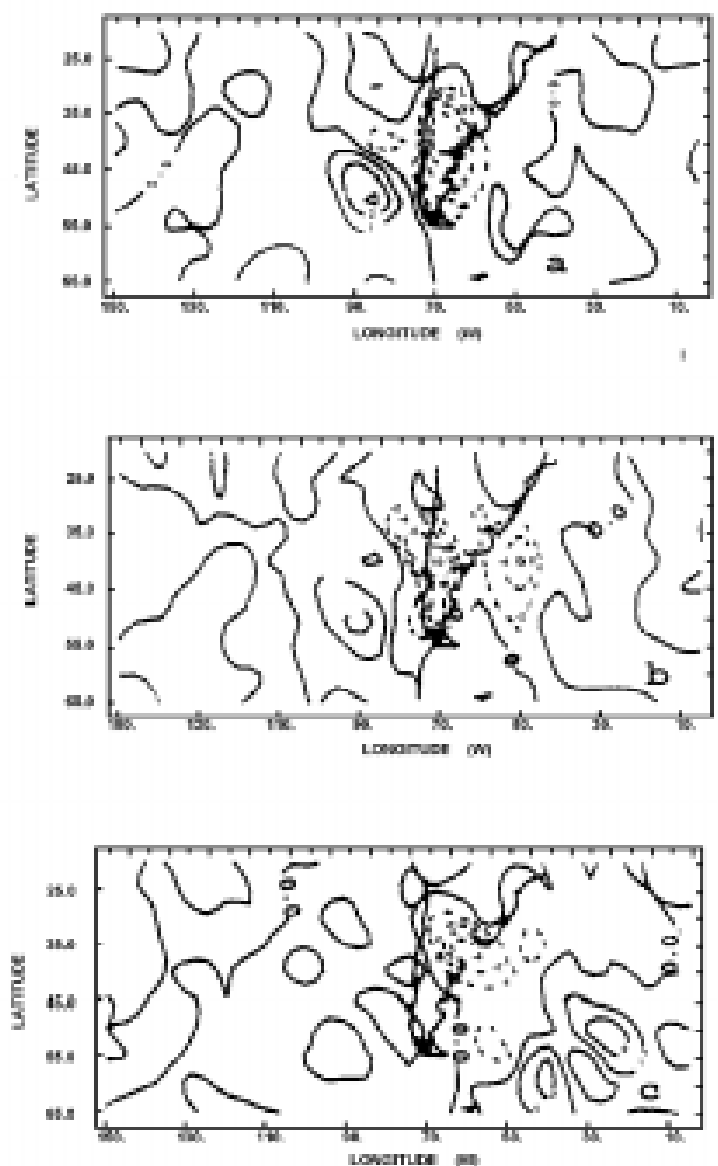

rigure / - Lonversion term between Kinetic energy between quasıstationary flow and high-pass filtered disturbances for cyclonic system composite. Units $\mathrm{Wm}^{-2}$. a) one day earlier, b) at the same time, c) one day later.

Figura 7 - Termo de conversão entre a energia cinética do escoamento quase estacionário e a energia cinética dos distúrbios filtrados com passa alta para o composto de sistemas ciclônicos. Unidades $W^{2}$.. a) 1 dia antes, b) no mesmo dia, c) 1 dia depois.

disturbance grows essentially by baroclinic conversion. In this case, the disturbance grows mainly due to the convergence of energy fluxes radiated by the waves upstream associated with the eddy ageostrophic advection off geopotential height.

Another factor to be considered is the pronounced low-level north-westerly moist flow over South America forced by the Andes Cordillera. When this flux entrains into a mid-latitude disturbance there is release of latent heat (James \& Anderson, 1984), and increases the growth rate of the disturbance.

\section{ACKNOWLEDGEMENTS}

Thanks are due to the official reviewers for their constructive suggestions to improve the manuscript.

\section{REFERENCES}

BONATTI, J.P. \& RAO, V. B. - 1987 - Moist baroclinic instability in the development of the North Pacific and South American intermediate-scale disturbances. Journal Atmosphere Sciences, 44: 2657-2667.

CHANG, E. K. M. - 1993 - Downstream development of baroclinic waves as inferred from regression analysis. Journal Atmosphere Sciences, 50: 2038-2053.

CHANG, E. K. M. \& ORLANSKI, I. - 1993 - On the dynamics of a storm track. Journal Atmosphere Sciences, 50: 999-1015.

GAN, M. A. \& RAO, V.B. - 1991 - Surface cyclogenesis over South America. Monthly Weather Review, 119: 1293-1302.

GAN, M. A. \& RAO, V.B. - 1994 - The influence of the Andes Cordillera on Transient Disturbances. Monthly Weather Review, 122: 1141-1157.

HAYASHI, Y. - 1980 - Estimation of nonlinear energy transfer spectra by the cross-spectral method. Journal Atmosphere Sciences, 37: 299-307.

HSU, H. H. - 1987 - Propagation of low-level circulation features in the vicinity of Mountain Ranges . Monthly Weather Review, 115: 1864-1892.

JAMES, I. N. \& ANDERSON, L. T. - 1984 - The seasonal mean flow and distribution of large-scale weather systems in the southern hemisphere: the effects of moisture transports. Quarterly Journal of Royal Meteorological Society, 110: 943-966.

LAU N. C. \& LAU, K.M. - 1984 - The structure and energetics of midlatitude disturbances accompanying cold-air outbreaks over East Asia. Monthly Weather Review, 112: 1309-1327.

LIN, S.C. \& SMITH, P.J. - 1979 - Diabatic heating and generation of available potential energy in a tornadoproducing extratropical cyclone. Monthly Weather Review, 107: 1169-1183.

LORENZ, E.N. - 1955 - Available potential energy and maintenance of the general circulation. Tellus, 7: 157 167.

O'BRIEN, J.J. - 1970 - Alternative solutions to the classical vertical velocity problem. Journal of Applied Meteorology, 9: 197-203.

OORT A. H. - 1964 - On estimates of the atmospheric energy cycle . Monthly Weather Review, 92: 483-493.

ORLANSKI, I. \& KATZFEY, J. - 1991 - The life cycle of a cyclone wave in the Southern Hemisphere. Part I: Eddy energy budget. Journal Atmosphere Sciences, 48: 1972-1998.

PLUMB, R. A. - 1983 - A new look at the energy cycle. Journal Atmosphere Sciences, 40: 1669-1688.

RANDEL, W.J. \& STANFORD, J. L. - 1985a - An observational study of medium-scale wave dynamics in the Southern Hemisphere summer. Part I: Wave structure and energetics. Journal Atmosphere Sciences, 42: 1172-1188. 
RANDEL, W.J. \& STANFORD, J. L. - 1985b - An observational study of medium-scale wave dynamics in the Southern Hemisphere summer. Part II: Stationary-transient wave interference. Journal Atmosphere Sciences, 42: 1189-1197.

RANDEL, W. J. \& STANFORD, J. L. - 1985c - The observational life cycle of a baroclinic instability. Journal Atmosphere Sciences, 42: 1364-1373.

SHENG, J. \& HAYASHI, Y. - 1990 - Estimation of atmospheric energetics in the frequency domain during the FGGE year. Journal Atmosphere Sciences, 47: 1255-1268.

WALLACE, J. M. \& LAU, N. C. - 1985 - On the role of barotropic energy conversion in the general circulation. Adv. Geophys., 28A: 33-74.

\section{ENERGETICA DOS DISTÚRBIOS DE ALTA FREQÜÊNCIA SOBRE A AMÉRICA DO SUL}

A atmosfera é um complexo sistema termodinâmico na qual conversões de energia ocorrem tanto na escala temporal como na espacial. Durante muito tempo estudouse as conversões de energia na escala espacial da forma proposta por Lorenz (1955), que introduziu o conceito de energia cinética (KE) e potencial disponível (APE) em duas componentes: a do estado básico e a da perturbação. Hayashi (1980) propôs um esquema que decompõem séries temporais das informações meteorológicas em componentes de Fourier, tal que as conversões de energia podem ser vistas através de espectros de diferentes faixas de freqüência. Com esse tipo de esquema é possível estudar as interações entre distúrbios de diferentes escalas de tempo.

Neste estudo discute-se a energética dos distúrbios de alta freqüência quando eles cruzam os Andes. A região da América do Sul é conhecida como sendo ciclogenética (Gan \& Rao, 1991), e em muitos casos os distúrbios transientes ao cruzar os Andes intensificam-se. Isto indica conversões locais de energia. Portanto, este estudo tem implicações importantes para a previsão do tempo.

Utiliza-se neste estudo os dados de temperatura, altura geopotencial e da componente zonal e meridional do vento em 10 níveis na vertical entre $1000 \mathrm{hPa}$ and 100 hPa, para o período de $1^{\circ}$ Janeiro de 1977 a 31 de Dezembro de 1979. Esses dados são as análise do "National Meteorological Center" (NMC) e estão em pontos de grade de $2,5^{\circ} \times 2,5^{\circ}$ longitude $\times$ latitude. Utiliza-se um filtro passa alta e passa baixa freqüência do tipo Gaussiano, com 9 pontos na série temporal. Esse filtro é essencialmente o mesmo utilizado por Lau \& Lau (1984), Hsu (1987) e Gan \& Rao (1994). Basicamente, as formulas clássicas utilizadas para o cálculo de KE e de APE foram modificadas substituindo as variáveis média zonal por filtradas com passa baixa, e as das perturbações pelas filtradas com passa-alta. As equações utilizadas são similares às de Plumb (1983).

A energética dos distúrbios de alta freqüência é estudada através de mapas compostos para situações de sistemas ciclônicos. Os mapas compostos são construídos para os casos quando a altura geopotencial filtrada com passa alta em $1000 \mathrm{hPa}$, no ponto base $70^{\circ} \mathrm{W}, 45^{\circ} \mathrm{S}$, encontrava-se abaixo de dois desvios padrões. Desta forma obtiveram-se 61 casos de sistemas ciclônicos.

A distribuição espacial da APE nos compostos dos ciclones é similar àquela obtida para os ciclones extratropicais do Hemisfério Norte, aumenta quando o sistema intensifica, e possui um máximo a $5^{\circ}$ corrente abaixo do ciclone. A conversão de APE do escoamento quase estacionário para APE dos distúrbios de alta freqüência mostra um padrão de valores positivos localizado a $5^{\circ}$ a leste do ciclone em $1000 \mathrm{hPa}$. Observouse também, que essa conversão está associada ao transporte de calor para o polo devido à circulação da Alta Subtropical do Atlântico Sul. A presença dos Andes, como um bloqueio natural, é um fator crucial para aumentar o fluxo de umidade e de ar quente nos baixos níveis para o polo. (James \& Anderson, 1984). Quando o ar tropical quente e úmido interage com sistemas de latitudes médias, há liberação de calor latente resultante da condensação. A liberação de calor latente aumenta a taxa de crescimento dos distúrbios baroclínicos (Bonatti \& Rao, 1987). Isto provavelmente explica os altos valores observados no termo residual $\left(\mathrm{R}_{\mathrm{AP}}\right)$ na fase inicial.

O mapa de conversão barotrópicas para o dia -1 (conversões de KE do escoamento quase-estacionário para KE dos distúrbios de alta frequiência) mostra um máximo sobre o oceano Pacífico leste próximo ao distúrbio, porém os valores são pequenos comparados aos do termo de conversão baroclínica. Esse resultado mostra que a instabilidade barotrópica pode contribuir para o crescimento dos distúrbios transientes.

Calcula-se também o balanço de APE e de KE dos casos dos compostos dos sistemas ciclônicos compreendido entre $30^{\circ} \mathrm{S}-55^{\circ} \mathrm{S}$ and $25^{\circ} \mathrm{W}-100^{\circ} \mathrm{W}$. O ciclo de energia das anomalias filtradas com passa alta mostra que esses distúrbios crescem por conversões baroclínicas, embora fluxos de energia chegando na região, e fontes não conservativas também são importantes durante essa fase. Após o estágio de maturidade, o distúrbio começa a decair barotropicamente e a energia radiativa é exportada para fora da região. Esse ciclo de energia parece ser similar ao observado por Orlanski \& Katzfey (1991) para o hemisfério sul e Chang (1993) para o hemisfério norte. 